\title{
ERRATUM
}

\section{AN EXTENDED FRAMEWORK FOR PREFERENCE RELATIONS - ERRATUM}

\author{
JOHAN E. GUSTAFSSON \\ Royal Institute of Technology
}

doi:10.1017/S0266267111000010, published by Cambridge University Press, 22 June 2011.

It is regretted that the originally published paper (Gustafsson, 2011a) was not the author's final amended version. We apologise for this oversight and reproduce the entire corrected paper here in print and online, with revised notation.

\section{REFERENCE}

Johan E. Gustafsson (2011a). AN EXTENDED FRAMEWORK FOR PREFERENCE RELATIONS. Economics and Philosophy, 27, pp 101-108. doi:10.1017/S0266267111000010 Johan E. Gustafsson (2011b). AN EXTENDED FRAMEWORK FOR PREFERENCE RELATIONS - CORRECTED VERSION. Economics and Philosophy, 27, pp 360-367. doi: $10.1017 /$ S0266267111000290 